\title{
FACTORS INFLUENCING OF PURCHASE BEHAVIOR: A STUDY CONDUCTED AMONG THE PURCHASERS OF FLAT IN CHIDAMBARAM
}

\author{
Dr. P. Balathandayutham 1 四, Dr. R. Sritharan 2 四 \\ ${ }^{1}$ Assistant Professor, Business Administration Government Arts and Science College, Valparai, \\ Tamil Nadu \\ ${ }^{2}$ Associate Professor, Business Administration, Annamalai Univeristy, Tamil Nadu
}

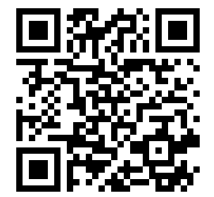

DOI: https://doi.org/10.29121/granthaalayah.v8.i7.2020.726

Article Type: Case Study

Article Citation: Dr. P.

Balathandayutham, and Dr. R.

Sritharan. (2020). FACTORS

INFLUENCING OF PURCHASE

BEHAVIOR: A STUDY CONDUCTED

AMONG THE PURCHASERS OF FLAT

IN CHIDAMBARAM. International

Journal of Research -

GRANTHAALAYAH, 8(7), 330-334.

https://doi.org/10.29121/granthaa

layah.v8.i7.2020.726

Received Date: 12 July 2020

Accepted Date: 31 July 2020

Keywords:

Buying Behaviour

Buying Attitude

Factors

Residential Satisfaction

\begin{abstract}
The current study was done to examine and investigate the factors that influence the purchase behavior among the flat purchaser in Chidambaram, Tamilnadu. Data were collected through structured questionnaire gleaned from the literatures. The respondents were selected using convenience sampling as it is the earliest and easiest method of implementing the sampling technique. The size of the sample population was determined as 100 and the questionnaire were used to collect the data. SPSS package was used for statistical analyses of the data. Regression analysis was performed to assess the influence of factors on buyer behaviour. The result of the study shows that factors are significantly influence on post purchase behavior of flat purchaser.
\end{abstract}

\section{INTRODUCTION}

Purchase of a house for residence is the dream of all people. In the world of heavy population and lack of sufficient land to provide individual land area for all, nowadays, apartment houses are becoming more popular. An apartment consists of many houses in multiple storeys and that too in a single piece of land. An apartment purchase is one among the most important decisions that a person takes in his/her lifetime.

\subsection{FACTORS AFFECTING PURCHASE DECISION OF RESIDENTIAL FLATS}

There are certain essential factors that the customers take into consideration before purchasing an apartment. Before making a purchase decision, the buyer goes into a detailed investigation of those factors which influence him to buy the apartment. the factors that make an impact on the purchase decision include; basic facilities, amenities

(C) 2020 The Author(s). This is an open access article distributed under the terms of the Creative Commons Attribution License, which permits unrestricted use, distribution, and reproduction in any medium, provided the original author and source are credited. 
for recreation and fun, the layout of the apartment, nearness to schools, hospitals, office and hospitals, availability of finance, goodwill of the builder, connectivity to the house and the surrounding. Let us now see some of these factors in detail:

\section{Basic Amenities of Residential Flats}

Basic amenities are those facilities without which the completion of a house cannot be done. Basic amenities include backup for power supply, water facility and proper system of sewage, sufficient space for car parking and easy access for domestic help in and around the residential area.

\section{Layout of Residential Flats}

The second factor that the buyer considers while buying an apartment is the layout. Various items are included under this factor. They include apartment's exterior look, floor design and quality, interior works, number of rooms including a separate room for the servants working in the house.

\section{Environmental and Location of Residential Flat}

Environmental factors are those which affect the peaceful day to day life of an individual. the items included in this factor are less noise due to traffic, safe and secure from crime, proximity to schools, good neighborhood and pleasant appearance of the residential area,

\section{Previous evidence regarding residential satisfaction}

Many researchers have carried out about the residential satisfaction with apartment industry (Balathandayutham, P., Sritharan, R.,2012; Balathandayutham, P., Sritharan, R., 2013a; Balathandayutham, P., Sritharan, R., 2013b; Balathandayutham, P., Sritharan, R., 2013c; Balathandayutham, P., Sritharan, R.,2013d; Balathandayutham, P., Sritharan, R.,2014a; Balathandayutham, P., Sritharan, R., 2014b: Balathandayutham, P., Sritharan, R.,2019), apartment satisfaction (Balathandayutham and sritharan 2014: Balathandayutham and sritharan 2017: Balathandayutham 2019), customer satisfaction in apartment (Balathandayutham, P., Sritharan, R., 2017; Balathandayutham, P., Sritharan, R.,2018), real estate marketing (Balathandayutham, P., Sritharan, R., 2012; Balathandayutham, P., Sritharan, R., 2013).

\section{STATEMENT OF PROBLEM}

The defects and problems in the previous edition of their building are solved and new apartments are built by the real estate developers after careful analysis of the evaluations done by the customers. The customers get satisfied only when the basic facilities and certain extra amenities for comfortable living are provided to them by the builders. This study is an attempt to examine those factors that make the customers feel satisfied in the purchase of the apartment.

\section{NEED FOR THE STUDY}

The study presented here is related to the influencing factors that make the customers to purchase an apartment. Further study has also been extended to assess the significance of each influencing factor. Hence this study will be helpful to the authorities responsible for promoting housing by carefully understanding the needs and requirements of the customers. The study will also help the flat promoters to know the preferences given to each influencing factor and satisfy those needs in the future.

\section{OBJECTIVES}

The current study was done to examine and investigate the factors that influence the purchase behavior among the flat purchaser in Chidambaram, Tamilnadu. Effort is also taken in the current study to offer valuable ideas to the flat promoters regarding the facilities that they can provide additionally to get more customers for the purchase of apartments. 


\section{REVIEW OF LITERATURE}

Mwfeq Haddad, Mahfuz Judeh and Shafig Haddad (2011) had done an empirical investigation on the factors that affect the purchase behavior of customers regarding apartments in the city of Amman in Jordan. The main aim of this paper was to assess the factors which influence the buying behavior of customers towards apartment purchase. It has also exhibited the factor that influences the purchase behavior to the maximum. The study performed convenience sampling to select the sample population. The sample size was 120 persons who have already purchased an apartment. The hypothesis of the study was tested using one-way ANOVA, an independent sample ttest and one sample t-test. The results of the study showed that customers gave their preference to factors like aesthetic features, marketing features, and geographical factors, social and economic factors. The results also showed that the decisions differed as per the age and gender of the sample population. On the other hand, it was found that decisions did not differ on the basis of education or marital status of the respondents.

Balathandayutham.P and Sritharan.R (2013) had performed a study on the examination of residential satisfaction regarding the services of apartment management. The data required for the purpose of the study was collected from the residents of Chidambaram. The sample population was selected through simple random sampling. The instrument used for data collection was a questionnaire of 18 questions and categorized into two divisions. A total of 200 questionnaires were distributed and 15 questionnaires were got back. The balance questionnaires were rejected due to unfair replies. ANOVA was performed to analyze the data. Age factor was considered and it was found that the respondents who were below the age of 30 are more satisfied when compared with the respondents who were above the age of 50 .

\section{RESEARCH METHODOLOGY}

The research was done only among the apartment purchaser in Chidambaram, Tamilnadu. The sample for the study was selected through convenience sampling as it is the earliest and easiest method of implementing the sampling technique. The sample size was 100 . Regression analysis was performed to find out the factors influence of apartment purchase.

\section{ANALYSIS AND INTERPRETATION}

Model Summary

\begin{tabular}{|c|c|c|c|c|}
\hline $\mathrm{R}$ & R Square & Adjusted R Square & F & Sig. \\
\hline $.997(\mathrm{a})$ & .993 & .993 & 6145.864 & $.000(\mathrm{a})$ \\
\hline
\end{tabular}

a Predictor: (Constant), Factors

Coefficients(a)

\begin{tabular}{|c|c|c|c|c|c|}
\hline & \multicolumn{2}{|c|}{ Unstandardized Coefficients } & \multirow{2}{*}{$\frac{\text { Standardized Coefficients }}{\text { Beta }}$} & \multirow[t]{2}{*}{$\mathrm{t}$} & \multirow[t]{2}{*}{ Sig. } \\
\hline & $\mathrm{B}$ & Std. Error & & & \\
\hline (Constant) & -.027 & .018 & & -1.493 & .136 \\
\hline Accessibility to market and shopping & .091 & .003 & .183 & 29.099 & .000 \\
\hline Adequate space between flats & .124 & .007 & .111 & 17.894 & .000 \\
\hline Bedroom & .074 & .005 & .092 & 14.553 & .000 \\
\hline Building and traffic density & .084 & .003 & .121 & 26.615 & .000 \\
\hline $\begin{array}{l}\text { Closeness to entertainment area } \\
\text { (Park, Playground, Theatre etc.) }\end{array}$ & .111 & .004 & .153 & 31.121 & .000 \\
\hline Closeness to worship place & .047 & .005 & .057 & 9.470 & .000 \\
\hline Community hall & .094 & .005 & .162 & 17.727 & .000 \\
\hline Corridor (long passage) & .090 & .005 & .164 & 19.510 & .000 \\
\hline Dining room & .078 & .005 & .132 & 15.216 & .000 \\
\hline Drainage service & .060 & .006 & .104 & 10.579 & .000 \\
\hline Electrical repair service & .093 & .004 & .130 & 23.601 & .000 \\
\hline
\end{tabular}


Factors Influencing of Purchase Behavior: A Study Conducted Among the Purchasers of Flat in Chidambaram

\begin{tabular}{|l|l|l|l|l|l|}
\hline Enforcement of rules & .066 & .005 & .100 & 13.137 & .000 \\
\hline
\end{tabular}

a Dependent Variable: post purchase behavior

The next pace was to examine the direction through which they are found to be related. Findings show that every statement of factors was significant. The table also revealed a positive coefficient, which means that among all the statements. There was a relation found between the influencing factors and post purchase behavior of flat purchase (dependent variable). The analysis done through regression exhibits that among 12, all factors are having an influence over the apartment. The coefficient value, $\mathrm{R}^{2}$, was found to be 0.993 through multiple regression, which shows that $99.3 \%$ of the independent variables had an influence on the purchase behavior of apartment.

\section{CONCLUSION}

This study will be helpful to the authorities responsible for promoting housing by carefully understanding the needs and requirements of the customers. The result of the study shows that, There was a relation found between the influencing factors and post purchase behavior of apartment (dependent variable). The coefficient value, $R^{2}$, was found to be 0.993 through multiple regression, which shows that $99.3 \%$ of the independent variables had an influence on the post purchase behavior of flats.

\section{SOURCES OF FUNDING}

This research received no specific grant from any funding agency in the public, commercial, or not-for-profit sectors.

\section{CONFLICT OF INTEREST}

The author have declared that no competing interests exist.

\section{ACKNOWLEDGMENT}

None.

\section{REFERENCES}

[1] Balathandayutham, P., Sritharan, R., "Marketing Strategies for consumer house buying behaviour", Revitalising Global Business, 994-995, 2012

[2] Balathandayutham, P., Sritharan, R., "A Study on Real Estate Marketing with Special Reference to Apartment Purchase", Selp Journal of Social Science 3 (12), 431-435, 2012

[3] Balathandayutham, P., Sritharan, R., "A Study on Role of Management Graduate's Services in Real Estate Business", M.S.R Journal of Management 1 (2), 116-118, 2013

[4] Balathandayutham, P., Sritharan, R., "Residential Satisfaction: An Empirical Study with Special Focus on Flat Purchase", International Journal of Applied Management Research 5 (special issue), 64-67, 2013

[5] Balathandayutham, P., Sritharan, R., "Detailed investigation of residential satisfaction in apartment's management service", International journal of research in commerce, it \& management 3 (09), 2013

[6] Balathandayutham, P., Sritharan, R., "A Focus on Factors Influencing Residential Satisfaction", Review Journal of Philosophy and Social Science 38 (2), 123-132, 2013

[7] Balathandayutham, P., Sritharan, R., "Service quality survey in apartment industry: a study on residential satisfaction among urban resident", IISRO Multi-conferences proceeding, 2013

[8] Balathandayutham, P., Sritharan, R., "A Study on the Residential Satisfaction among the Elderly in Chennai", International Journal of Research in Management Studies (IJRMS) 6 (1), 6-9, 2014

[9] Balathandayutham, P., Sritharan, R., "Factorial Study on Residential Satisfaction of Apartment Residents", Sankhya International Journal of Management and Technology 3 (II (a)), 79-80, 2014 
[10] Balathandayutham, P., Sritharan, R., "A study on the influence of service quality on Apartment Satisfaction in Chennai, Tamilandu", Bonfring International Journal of Industrial Engineering and Management, 2014

[11] Balathandayutham, P., "A study on antecedent and consequences of customer satisfaction in apartment culture at Chennai," International Journal of Management Studies, Vol-III, Issue-1, February 2016, 129-139, 2016

[12] Balathandayutham, P., "A study on perceived risk of residential construction companies and its customers", International Journal of Management Studies, Vol-IV, Issue-1, June 2017, 181 -186, 2017

[13] Balathandayutham, P., "A Study on the Satisfaction of the Elderly People in Apartment Culture”, International Journal of Management Studies, Vol.-V, Issue -1(3), 145-150, 2018

[14] Balathandayutham, P., "Influence of apartment price on residential satisfaction: a study in Chennai", International journal of research in computer application \& management, volume no. 9, issue no. 11 (November), 5-7, 2019.

[15] Balathandayutham, P., Anandanatarajan, K., Sritharan, R., "Brand Preference in Indian FMCG Industries: An Emprical Study", INDIFED, Symposium, Chennai, 2012.

[16] Balathandayutham, P., Anandanatarajan, K., "Price and Green Attitude Towards Environmental Friendly Product in Chidambaram", Review of Research Journal, Special Issue Volume 1 November 2019, Page 226231

[17] Manivannan and. Somasundaram;(2014), Purchase of Residential Flats - Factors Influencing the Decision of Buyers in Selected Cities in Tamil Nadu: IRJBM - (www.irjbm.org) Volume No - VII September - 2014 Issue - 9 Page 67

[18] Mostafa Kamal and Shah Alam Kabir Pramanik (2015); Factors Affecting Customers to Buy Apartments in Dhaka City Daffodil International University Journal of Business and Economics, Vol. 9, No. 2, PP. 37-49, December, 2015

[19] Mwfeq Haddad, Mahfuz Judeh and Shafig Haddad (2011) Factors Affecting Buying Behavior of an Apartment an Empirical Investigation in Amman, Jordan. Research Journal of Applied Sciences, Engineering and Technology, (03): 234-239.

[20] Nasar K K and Dr. Manoj P K (2014) Factors Influencing the Purchase of Apartments; CLEAR IJRMST Volume04 Issue-08 Jul-Dec 2014 